\title{
Cost modelling for flotation machines
}

\author{
by S. Arfania*, A.R. Sayadi*t, and M.R. Khalesi*
}

\section{Synopsis}

Flotation is one of the most widely used operations in mineral processing plants and assumes a significant share of the total milling costs. The purpose of this paper is to introduce a new set of capital and operating cost models for major flotation machines based on the application of single (SRA) and multiple regression analysis (MRA). Thirty-seven major flotation machines were analysed for this purpose. Depending on the machinery type, different technical variables such as diameter, required air flow rate, required floor space, cell volume, required air pressure, and power were considered as predictor variables, individually (in SRA) or simultaneously (in MRA). Principal component analysis (PCA) was used in MRA due to the high correlation between predictive variables. The performance of each model was evaluated using $\mathrm{R}^{2}$, MAER (mean absolute error rate), and residual analysis. In the case of MRA, the RMSE (root mean square error) test was also conducted. Maximum obtained MAER of $13.5 \%$ and minimum $R^{2}$ of 0.86 indicated that these models could be applied as credible tools in estimation of capital and operating costs of flotation machines for design and feasibility studies.

\section{Keywords}

cost estimation, flotation machine, regression model, principal component analysis.

\section{Introduction}

Mineral processing is a vital part of mining projects and mainly involves comminution, sizing, concentration, extractive metallurgical processes, and dewatering. Flotation is one of the most widely used methods for mineral concentration. Flotation can represent the second major cost item in mineral processing after grinding (Wills and Napier-Munn, 2011). Accordingly, it is a main concern of mining project managers to select and optimize flotation circuits in order to decrease costs and increase productivity. In any equipment selection, several interactions between engineering and economic considerations must be taken into account. Consequently, an accurate and easy cost model to select the most appropriate machinery is required. Moreover, cost models could be used in flow sheet simulations applied in design and optimization. Models of unit operations built into the simulators could be improved by linking the equipment cost models (Khalesi $e t$ al., 2015).
A number of approaches can be employed with the aim of developing the cost models. A review of these methods can be found in recent papers by Niazi et al. (2006) and Huang, Newnes, and Parry (2012). Regression is one the most frequently applied techniques for cost modelling (Smith and Mason, 1997). Several cost models have been established related to mining and milling projects (Table I). One of the preliminary works was undertaken by Prasad (1969) and has been carried on in the recent work of Sayadi, Khalesi, and Khosfarman (2014). Almost all of these models have been developed based on exponential single regression approaches; correlating only one independent variable to a cost value (Stebbins, 1987). Consequently, in spite of the usefulness of these models in preliminary cost estimation, the role of other effective parameters has simply been overlooked. Some of these models have become old and updating them also may cause significant errors. Furthermore, these models mainly estimate total operating cost, and estimation of detailed operating cost items such as maintenance, lubrication, etc. is not possible. To overcome these deficiencies, this paper aims to introduce up-to-date capital and detailed operating cost models considering multiple effective factors of flotation machines. Two sets of single (SRA) and multiple regression (MRA) cost functions are presented. The first set is suitable for cost estimation at the initial phases of a project and is mainly appropriate for building rapid cost estimates where only one particular design factor of a flotation machine is accessible. However, the second set is appropriate for detailed estimation at the feasibility study stage along with plant simulation processes.

* Tarbiat Modares University, Iran.

+ Corresponding author.

(c) The Southern African Institute of Mining and Metallurgy, 2017. ISSN 2225-6253. Paper received Apr. 2015; revised paper received Jul. 2016. 


\section{Cost modelling for flotation machines}

Table I

A brief history of cost estimation in mining and milling projects

\begin{tabular}{|c|c|c|}
\hline Author & Year & Theme \\
\hline Mohutsiwa and Musingwini & 2015 & Parametric capital costs estimation for coal mines in South Africa \\
\hline Sayadi et al. & 2014 & Parametric cost modeling for mineral grinding mills \\
\hline Lashgari and Sayadi & 2013 & Overhaul and maintenance cost of loading equipment in surface mining \\
\hline Sayadi et al. & 2012 & Estimating capital and operational costs of backhoe shovels \\
\hline Sayadi et al. & 2011 & Hard-rock LHD cost estimation using regression techniques \\
\hline McNab & 2009 & Simplified cost estimation for processing of iron ores \\
\hline Loh et al. & 2002 & Processing equipment cost estimation \\
\hline Mular & 1978 & Estimation of capital costs of mining and mineral processing equipment using regression analysis \\
\hline Mular & 1982 & Estimation of capital costs of mining and mineral processing equipment using regression analysis \\
\hline Mular and Poulin & 1998 & Estimation of capital costs of mining and mineral processing equipment using regression analysis \\
\hline Camm & 1994 & Cost modeling for mine and mill \\
\hline Noakes and Lanz & 1993 & Estimating the costs of mining and milling industry, using graphical or formulation methods \\
\hline O’Hara & 1980 & Development of a set of cost formulas as estimators of capital and operating costs of mining and milling \\
\hline O'Hara and Suboleski & 1992 & Development of a set of cost formulas as estimators of capital and operating costs of mining and milling \\
\hline Pascoe & 1992 & Capital and operating costs of minerals engineering plants \\
\hline USBM & 1987 & Estimation of mining and milling costs using regression analysis \\
\hline Prasad & 1969 & Mineral processing plant design and cost estimation \\
\hline
\end{tabular}

Table II

Data description of flotation machines

\begin{tabular}{|c|c|c|c|c|c|c|c|}
\hline Item & & & & Min & Max & Mean & Standard deviation \\
\hline \multirow[t]{8}{*}{ Column } & \multirow[t]{4}{*}{ Sulfide } & \multirow[t]{2}{*}{ Variables } & Diameter (m) & 0.91 & 4.00 & 2.28 & 0.95 \\
\hline & & & Required air flow rate (m³/min) & 8.50 & 850.00 & 212.97 & 261.18 \\
\hline & & \multirow[t]{2}{*}{ Costs } & Capital (US\$) & 112600 & 393700 & 224558 & 78526 \\
\hline & & & Operating (US\$/h) & 3.25 & 11.36 & 6.48 & 2.27 \\
\hline & \multirow[t]{4}{*}{ Coal } & \multirow[t]{2}{*}{ Variables } & Diameter $(\mathrm{m})$ & 2.4 & 4.3 & 3.35 & 0.82 \\
\hline & & & Required air flow rate (m³/min) & 850 & 3398 & 1876.25 & 1152.20 \\
\hline & & \multirow[t]{2}{*}{ Costs } & Capital (US\$) & 179200 & 289400 & 240200 & 45801 \\
\hline & & & Operating (US\$/h) & 5.17 & 8.35 & 6.92 & 1.32 \\
\hline \multirow{5}{*}{\multicolumn{2}{|c|}{ Self-aerating }} & \multirow[t]{3}{*}{ Variables } & Cell volume $\left(\mathrm{m}^{3}\right)$ & 0.31 & 85 & 17.20 & 26.22 \\
\hline & & & Required floor space $\left(\mathrm{m}^{2}\right)$ & 0.83 & 23.2 & 7.56 & 7.44 \\
\hline & & & Power $(\mathrm{kW})$ & 2.23 & 149.14 & 35.96 & 46.56 \\
\hline & & \multirow[t]{2}{*}{ Costs } & Capital (US\$) & 17800 & 279900 & 74372.73 & 77819 \\
\hline & & & Operating (US\$/h) & 0.51 & 8.07 & 2.14 & 2.24 \\
\hline \multirow[t]{6}{*}{ Standard } & & \multirow[t]{4}{*}{ Variables } & Cell volume $\left(\mathrm{m}^{3}\right)$ & 0.28 & 158.6 & 35.64 & 52.87 \\
\hline & & & Required air flow rate $\left(\mathrm{m}^{3} / \mathrm{min}\right)$ & 0.42 & 85 & 21.11 & 28.42 \\
\hline & & & Air pressure required (kP) & 10.34 & 103.42 & 32.95 & 31.29 \\
\hline & & & Power $(\mathrm{kW})$ & 1.11 & 149.14 & 35.94 & 48.79 \\
\hline & & \multirow[t]{2}{*}{ Costs } & Capital (US\$) & 17600 & 302600 & 100580 & 95962 \\
\hline & & & Operating (US\$/h) & 0.51 & 8.73 & 2.89 & 2.77 \\
\hline
\end{tabular}

\section{Methodology}

\section{Data}

Thirty-seven major flotation machines (16 columns, 11 selfaerating, and 10 standard cells) are considered in this study. The data descriptions are presented in Table II (InfoMine, 2013). InfoMine conducts annual surveys on costs of equipment from manufacturers and distributors; fuel, energy, and lubricant suppliers; and US mining companies and provides the data without mentioning the manufacturers' names:
Column flotation: based on 36-foot, mild steel column, includes automatic sparger system, wash water system, and level control

> Self-aerating cells: individual cells based on a 10-cell row and including paddles, feed boxes, junction boxes, discharge boxes, skimmer drives, and motor guards, but not motors or launders

> Standard cells: individual cells based on a 10-cell row and including paddles, feed boxes, junction boxes, discharge boxes, skimmer drives, and motor guards, but not motors, blowers, and launders. 


\section{Cost modelling for flotation machines}

The data contained technical and cost specifications of the machines. Technical parameters were diameter $(D)$, required air flow rate $(\mathrm{AF})$, cell volume (CV), required floor space (FS), required air pressure (AP) and power $(P)$ depending on the type of flotation machine (Figure 1). These parameters were individually or simultaneously used as predictor variables in cost models.

Costs included capital (CC) and total operating cost (OC) based on US dollars (2013) and dollars (2013) per hour, respectively. Moreover, the operating costs could also be estimated in detail, i.e. the overhaul (parts and labour), maintenance (parts and labour) and lubrication cost items. The operating costs data is provided based on certain unit costs in the USA in 2013: electrical power, lubricant and repair labour were assumed as 0.076 US\$ per kWh, 3.32 US\$ per litre, and 37.57 US\$ per hour, respectively.

The overhaul costs (including both parts and labour) are those associated with scheduled refurbishing or replacement of major wear parts. Likewise, the maintenance costs (including both parts and labour) are associated with both unscheduled repairs and scheduled servicing of all of minor and major components, excluding overhaul actions and lubrication. The cost of operator's time was not included in this study. The data and therefore the developed models represent flotation machines with separate motors. The costs of motors are generally estimated separately. Here, for ease of use of the models, separate capital and operating cost functions for variable-speed DC motors are provided later.

\section{Statistical approach}

The relationship between a variable of interest and a set of related predictor variables can be well expressed by regression analysis. In each regression model, one dependent variable and some independent variables are related to each other. The regression is called single regression (SRA) if just one independent variable exists, while in multiple linear regression (MRA) several independent variables are correlated to the dependent variable. In this regard, independency of regressors (so-called independent variables) is a must. Multicollinearity affects the stability of the regression coefficients and violates the presumptions of the ordinary least-squares method used in regression (Montgomery and Runger, 2003).

In this paper, both single and multiple regression analysis were conducted on the data. MATLAB software was used in order to evaluate different univariate structures for capital

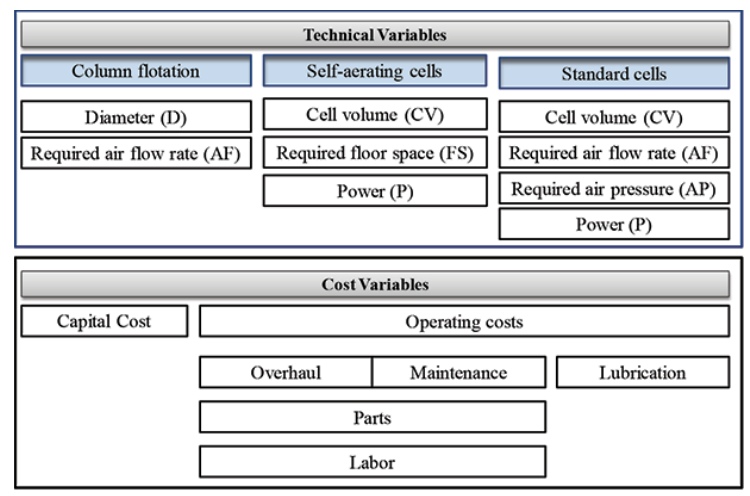

Figure 1-Variables of flotation machines and operating costs and as a result, the power function framework of Equation [1] was chosen for the univariate model:

$$
Y=a X^{b}
$$

where $Y$ refers to capital or operating costs, $X$ defines an independent variable (one of the machine predictor variables), and $a$ and $b$ are constant values (parameters) of the models.

In the case of multivariate models, the multiple linear regression framework (Equation [2]) showed promise in this research, based on testing different model structures and also on previous works (Sayadi, Khalesi, and Khosfarman, 2014).

$$
Y=C+a_{1} x_{1}+a_{2} x_{2}+\ldots+a_{n} x_{n}
$$

where $x_{i}$ defines independent explanatory variables and $a_{i}$ are regression coefficients (model parameters). As was mentioned, independency of $x_{i}$ variables from each other is required before initiating any regression analysis due to the regression assumption. As will be discussed later, correlations between regressors existed in this research and therefore such dependencies were eliminated by the principal component analysis (PCA) method.

For evaluation of the SRA models, $\mathrm{R}^{2}$, RMSE (root mean square error), and MAER (means absolute error rate) were carried out. $\mathrm{R}^{2}$ is the coefficient of determination and indicates measures of the dependent variable variance which is explained by the regression model. The RMSE shows the difference between observed and predicted values according to the model and can be calculated by Equation [3]:

$$
R M S E=\sqrt{\frac{\sum_{i=1}^{n}\left(X_{o b s, i}-X_{e, i}\right)^{2}}{n}}
$$

where $X_{o b s}$ is the observed value, $x_{e}$ the estimated value at time/place $I$, and $n$, is the number of observations.

For evaluation of the MRA models, analysis of residuals, tests of MAER values and evaluation of $\mathrm{R}^{2}$ were conducted. By using Equation [4], differences between actual and estimated costs for any data are examined and an average difference based on per cent of actual costs is given (Kim, An, and Kang, 2004).

$$
\text { MAER }=\frac{1}{n} \sum_{i=1}^{n}\left(\left(C_{e_{i}}-C_{a_{i}}\right) / C_{a_{i}}\right)
$$

where $C_{e}$ is the estimated cost, $C_{a}$ the actual cost, and $n$ the number of data. MAER values should be in low levels as much as possible.

\section{Principal component analysis}

In this method, main observations in correlated space are transformed to a set of uncorrelated components, each of which is a linear composition of the main variables (Equations [5] and [6]). The new uncorrelated variables are called principal components (PCs). As can be seen in Figure 2, neither $X_{1}$ nor $X_{2}$ is the main direction of the data, while the ellipse with main diameters $\mathrm{PC}_{1}$ and $\mathrm{PC}_{2}$ matches the direction of the data. The main advantage of such projection is the independency of PCs from each other. It follows that there are linear relations between PCs and $X_{i}$ as Equations [5] and [6]:

$$
P C_{1}=w_{1} X_{1}+w_{2} X_{2}
$$




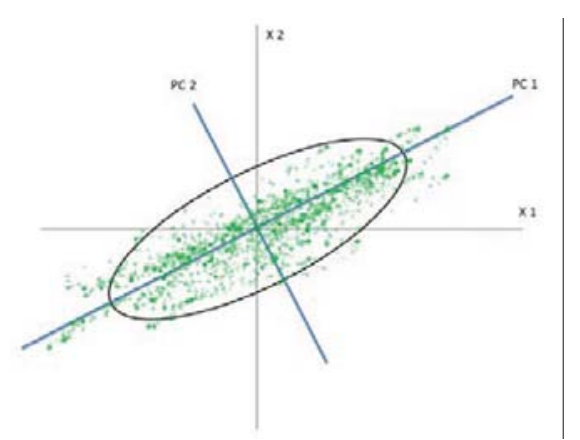

Figure 2-PCs axis vs. main axis

$$
P C_{2}=w_{1} X_{1}+w_{2} X_{2}
$$

In this research, main variables of $X_{1}, X_{2} \ldots X_{n}$ were first transformed into PCs in order to eliminate the multicollinearity, and then the multiple linear regression model was built with PCs as the regressors. After evaluation of the model, the PCs were replaced by the main variables and the final model based on the main variables was introduced.

\section{Steps of development of MRA models}

To clarify the steps by which multivariable costs models have been obtained, the development of capital cost function for the column sulphide flotation machine (CSFM) is presented here as an example. Table III illustrates the high correlation between predictor variables for the CSFM.

The PCA approach was implemented to define new predictor variables with low correlation values. Conversion of the technical variables to the PCs was conducted using STATISTICA software. Table IV shows the main variables and the new generated PCs of the CSFM together, while Table V demonstrates the correlation matrix of the new PCs. As can be seen, the new PCs are completely independent from each other and therefore multiple regression models can be built using PCs as regressors.

Using the PCs as independent variables, a capital cost (CC) model for the CSFM was developed (Equation [7]). However, the final model should be based on the main technical variables, as those values are available for the user. Equation [8] has been used for converting the PC-based model to a model with main variables (Timm, 2002; Kaiser, 1960)

$$
\begin{aligned}
& C C=224558.3+54288.25 P C_{1}+40724.7 P C_{2} \\
& \mathrm{Y}=\mathrm{X}_{\mathrm{i}}\left(\frac{\alpha_{\mathrm{i}}}{\mathrm{S}_{\mathrm{i}, \mathrm{x}}}\right)-\sum\left[\left(\alpha_{\mathrm{i}} \cdot \mathrm{X}_{\mathrm{i}, \mathrm{ave}}\right) / \mathrm{S}_{\mathrm{i}, \mathrm{x}}+\mathrm{C}\right]
\end{aligned}
$$

where $X_{i}$ are main technical variables (like power or required air), $a_{\mathrm{i}}$ are calculated by multiplication of coefficients of the model based on PCs as predictors by the eigenvectors of PCs (as illustrated in Figure 3), $\mathrm{S}_{\mathrm{ix}}$ and $\mathrm{X}_{\mathrm{i} \text { ave }}$ are the standard deviation and mean of main variables, respectively (can be found from Table II) and C refer to constant value of PCbased model (here 224558.3 ). Equation [9] shows the final capital cost model for the CSFM.

$$
C C=55057.22+70938.63 D+36.72 A F
$$

\section{Results and discussion}

\section{Single regression results}

Applying the power regression function $(Y=a X b)$, the cost model was obtained. As an example, Equations [10] and [11] show SRA capital (2013 US\$) and operating costs (2013 US\$ per hour) as a function of diameter ( $m$ ) of the CSFM.

$$
C C=118226.4 D^{0.791}
$$

Table III

\section{Correlation between technical variables) CSFM)}

Correlations

Marked correlations are significant at $p<0.05000$

$\mathrm{N}=12$ (Casewise deletion of missing data)

\begin{tabular}{|l|c|c|c|c|}
\hline & Mean & Std. dev. & Diameter & Required air flow rate \\
\hline Diameter & 2.2792 & 0.9471 & 1.000000 & 0.931963 \\
\hline $\begin{array}{l}\text { Required air } \\
\text { flow rate }\end{array}$ & 212.9667 & 261.1806 & 0.931963 & 1.000000 \\
\hline
\end{tabular}

Table IV

Technical variable values vs. generated PCs (CSFM)

\begin{tabular}{|l|c|c|c|}
\hline $\boldsymbol{X}_{\mathbf{1}}$ (D) & $\boldsymbol{X}_{\mathbf{2}}$ (AF) & $\mathbf{P C}_{\mathbf{1}}$ & $\mathbf{P C}_{\mathbf{2}}$ \\
\hline 0.91 & 8.5 & -1.57581 & -0.468686 \\
1.22 & 11.3 & -1.33678 & -0.244814 \\
1.52 & 22.7 & -1.08193 & -0.051691 \\
1.68 & 50.1 & -0.88829 & -0.006414 \\
1.82 & 68 & -0.73530 & 0.049652 \\
2.1 & 102 & -0.43419 & 0.166656 \\
2.3 & 136 & -0.19282 & 0.223930 \\
2.4 & 170 & -0.02611 & 0.206542 \\
2.7 & 227 & 0.35220 & 0.276210 \\
3.0 & 312 & 0.80631 & 0.270071 \\
3.7 & 598 & 2.10324 & 0.018404 \\
4.0 & 850 & 3.00948 & -0.439861 \\
\hline
\end{tabular}

Table $\mathrm{V}$

Correlation coefficients between PCs of CSFM

Correlations marked correlations are significant at $\mathrm{p}<.05000 \mathrm{~N}=12$ (casewise deletion of missing data)

\begin{tabular}{|l|c|c|c|c|}
\hline & Mean & Std. dev. & PC $_{1}$ & $\mathbf{P C}_{2}$ \\
\hline $\mathrm{PC}_{1}$ & 0.0 & 1.389951 & 1.0 & 0.0 \\
$\mathrm{PC}_{2}$ & 0.0 & 0.260839 & 0.0 & 1.0 \\
\hline
\end{tabular}

$$
\begin{aligned}
& \begin{array}{ccc}
\text { Eigenvectors } & \begin{array}{c}
\text { PC } \\
\text { Coefficient }
\end{array} & \begin{array}{c}
\text { Final } \\
\text { Coefficien }
\end{array}
\end{array} \\
& {\left[\begin{array}{ll}
0.707107 & 0.707107 \\
0.707107 & 0.707107
\end{array}\right]\left[\begin{array}{c}
54288.25 \\
40724.7
\end{array}\right]=\left[\begin{array}{l}
70938.47 \\
36.72185
\end{array}\right]} \\
& {\left[\begin{array}{ll}
0.707107 & -0.707107
\end{array}\right]\left[\begin{array}{l}
5424.7
\end{array}\right]=\left[\begin{array}{l}
70728.72185
\end{array}\right]}
\end{aligned}
$$

Figure 3-Final model coefficient generation 


\section{Cost modelling for flotation machines}

$$
O C=3.41 D^{0.790}
$$

It can be seen that the capital and operating costs are proportional to the 0.791 and 0.790 power of diameter in the case of the column sulphide flotation machine. The $\mathrm{R}^{2}$ is about 0.94 for both cases, i.e. $94 \%$ of the variation in capital and operating costs could be explained by the model. Tables VI to IX demonstrate results for the machines modelled in this research.

\section{Multiple regression results}

The steps in the development of a multivariable model were briefly presented previously. As was mentioned, the validity of regression models like Equation [9] were tested by different statistical approaches. Figure 4 shows the residuals of the capital cost model of the CSFM, confirming their correct normal distribution. Table $\mathrm{X}$ represents the coefficients of the final MRA models $\left(\mathrm{a}_{1}, \mathrm{a}_{2}, \mathrm{a}_{3}\right)$ and new intercept $\left(\mathrm{a}_{0}\right)$ along

\section{Table VI}

Single regression analysis for column (sulphide) flotation machine (CSFM)

\begin{tabular}{|c|c|c|c|c|c|c|c|c|c|c|}
\hline \multirow{3}{*}{$\begin{array}{l}\text { Explanatory } \\
\text { variable }\end{array}$} & \multirow{3}{*}{$\begin{array}{c}\text { Model } \\
\text { description }\end{array}$} & \multirow{3}{*}{$\begin{array}{c}\text { Capital } \\
\text { cost }\end{array}$} & \multicolumn{7}{|c|}{ Operating costs } & \multirow{3}{*}{$\begin{array}{l}\text { Lubrication } \\
\text { cost }\end{array}$} \\
\hline & & & \multirow{2}{*}{$\begin{array}{l}\text { Total operating } \\
\text { cost }\end{array}$} & \multicolumn{3}{|c|}{ Overhaul } & \multicolumn{3}{|c|}{ Maintenance } & \\
\hline & & & & Parts & Labour & Total & Parts & Labour & Total & \\
\hline $\begin{array}{l}\text { Diameter } \\
\text { (m) }\end{array}$ & $\begin{array}{c}a \\
b \\
R^{2} \\
\text { MAER } \\
\text { RMSE }\end{array}$ & $\begin{array}{c}118226.4 \\
0.79101 \\
0.9379 \\
4.86 \\
113.90\end{array}$ & $\begin{array}{c}3.410613 \\
0.790883 \\
0.9377 \\
4.88 \\
0.61\end{array}$ & $\begin{array}{c}0.493788 \\
0.790591 \\
0.9391 \\
4.77 \\
0.23\end{array}$ & $\begin{array}{c}0.462357 \\
0.795579 \\
0.9375 \\
4.86 \\
0.23\end{array}$ & $\begin{array}{c}0.914055 \\
0.791869 \\
0.9369 \\
4.83 \\
0.32\end{array}$ & $\begin{array}{c}0.914055 \\
0.791869 \\
0.9369 \\
4.83 \\
0.32\end{array}$ & $\begin{array}{c}0.861211 \\
0.792835 \\
0.9387 \\
4.85 \\
0.31\end{array}$ & $\begin{array}{c}1.7752 \\
0.7923 \\
0.9378 \\
4.84 \\
0.44\end{array}$ & $\begin{array}{c}0.673749 \\
0.793598 \\
0.9383 \\
4.82 \\
0.27\end{array}$ \\
\hline
\end{tabular}

Table VII

Single regression analysis for column (coal) flotation machine (CCFM)

\begin{tabular}{|c|c|c|c|c|c|c|c|c|c|c|}
\hline \multirow{3}{*}{$\begin{array}{l}\text { Explanatory } \\
\text { variable }\end{array}$} & \multirow{3}{*}{$\begin{array}{c}\text { Model } \\
\text { description }\end{array}$} & \multirow{3}{*}{$\begin{array}{c}\text { Capital } \\
\text { cost } \\
\text { cost }\end{array}$} & \multicolumn{7}{|c|}{ Operating costs } & \multirow{3}{*}{$\begin{array}{l}\text { Lubrication } \\
\text { cost }\end{array}$} \\
\hline & & & \multirow{2}{*}{$\begin{array}{c}\text { Total operating } \\
\text { Parts }\end{array}$} & \multicolumn{3}{|c|}{ Overhaul } & \multicolumn{3}{|c|}{ Maintenance } & \\
\hline & & & & Labour & Total & Parts & Labour & Total & & \\
\hline Diameter (m) & $\begin{array}{c}a \\
b \\
R^{2} \\
\text { MAER } \\
\text { RMSE }\end{array}$ & $\begin{array}{c}95523.91 \\
0.765573 \\
0.9284 \\
11.63 \\
94.46\end{array}$ & $\begin{array}{c}2.754794 \\
0.765628 \\
0.9290 \\
11.45 \\
0.51\end{array}$ & $\begin{array}{c}0.4006 \\
0.7614 \\
0.9282 \\
12.02 \\
0.19\end{array}$ & $\begin{array}{c}0.3691 \\
0.7780 \\
0.9285 \\
11.89 \\
0.19\end{array}$ & $\begin{array}{c}0.7697 \\
0.76950 \\
0.9284 \\
11.64 \\
0.27\end{array}$ & $\begin{array}{c}0.74194 \\
0.76200 \\
0.9315 \\
11.80 \\
0.26\end{array}$ & $\begin{array}{c}0.7013 \\
0.7603 \\
0.9271 \\
11.53 \\
0.26\end{array}$ & $\begin{array}{c}1.4433 \\
0.76122 \\
0.9294 \\
11.66 \\
0.36\end{array}$ & $\begin{array}{c}0.543649 \\
0.76731 \\
0.9246 \\
11.53 \\
0.23\end{array}$ \\
\hline
\end{tabular}

Table VIII

Single regression analysis for self-aerating flotation machine (SAFM)

\begin{tabular}{|c|c|c|c|c|c|c|c|c|c|c|}
\hline \multirow{3}{*}{$\begin{array}{l}\text { Explanatory } \\
\text { variable }\end{array}$} & \multirow{3}{*}{$\begin{array}{c}\text { Model } \\
\text { description }\end{array}$} & \multirow{3}{*}{$\begin{array}{c}\text { Capital } \\
\text { cost }\end{array}$} & \multicolumn{7}{|c|}{ Operating costs } & \multirow{3}{*}{$\begin{array}{c}\text { Lubrication } \\
\text { cost }\end{array}$} \\
\hline & & & \multirow{2}{*}{$\begin{array}{c}\text { Total operating } \\
\text { cost }\end{array}$} & \multicolumn{3}{|c|}{ Overhaul } & \multicolumn{3}{|c|}{ Maintenance } & \\
\hline & & & & Parts & Labour & Total & Parts & Labour & Total & \\
\hline $\begin{array}{l}\text { Cell volume } \\
\left(\mathrm{m}^{3}\right)\end{array}$ & $\begin{array}{c}a \\
b \\
R^{2} \\
\text { MAER } \\
\text { RMSE }\end{array}$ & \begin{tabular}{|c|}
23907.727 \\
0.469 \\
0.8655 \\
11.63 \\
110.92
\end{tabular} & $\begin{array}{c}0.690 \\
0.469 \\
0.8655 \\
11.45 \\
0.59\end{array}$ & $\begin{array}{c}0.098 \\
0.474 \\
0.8671 \\
12.02 \\
0.23\end{array}$ & $\begin{array}{c}0.092 \\
0.474 \\
0.8700 \\
11.89 \\
0.22\end{array}$ & $\begin{array}{c}0.190 \\
0.474 \\
0.8685 \\
11.64 \\
0.31\end{array}$ & $\begin{array}{c}0.186 \\
0.467 \\
0.8611 \\
11.80 \\
0.31\end{array}$ & $\begin{array}{c}0.175 \\
0.467 \\
0.8624 \\
11.53 \\
0.30\end{array}$ & $\begin{array}{c}0.361 \\
0.467 \\
0.8618 \\
11.66 \\
0.43\end{array}$ & $\begin{array}{c}0.137 \\
0.469 \\
0.8665 \\
11.53 \\
0.26\end{array}$ \\
\hline
\end{tabular}

Table IX

Single regression analysis for standard flotation machine (SFM)

\begin{tabular}{|c|c|c|c|c|c|c|c|c|c|c|}
\hline \multirow{3}{*}{$\begin{array}{l}\text { Explanatory } \\
\text { variable }\end{array}$} & \multirow{3}{*}{$\begin{array}{c}\text { Model } \\
\text { description }\end{array}$} & \multirow{3}{*}{$\begin{array}{c}\text { Capital } \\
\text { cost }\end{array}$} & \multicolumn{7}{|c|}{ Operating costs } & \multirow{3}{*}{$\begin{array}{l}\text { Lubrication } \\
\text { cost }\end{array}$} \\
\hline & & & \multirow{2}{*}{$\begin{array}{c}\text { Total operating } \\
\text { cost }\end{array}$} & \multicolumn{3}{|c|}{ Overhaul } & \multicolumn{3}{|c|}{ Maintenance } & \\
\hline & & & & Parts & Labour & Total & Parts & Labour & Total & \\
\hline $\begin{array}{l}\text { Cell volume } \\
\left(\mathrm{m}^{3}\right)\end{array}$ & $\begin{array}{c}a \\
b \\
\text { R2 } \\
\text { MAER } \\
\text { RMSE }\end{array}$ & $\begin{array}{c}25351.280 \\
0.452 \\
0.9561 \\
10.82 \\
108.32\end{array}$ & $\begin{array}{c}0.715 \\
0.457 \\
0.9571 \\
11.99 \\
0.58\end{array}$ & $\begin{array}{c}0.103 \\
0.460 \\
0.9618 \\
9.93 \\
0.21\end{array}$ & $\begin{array}{c}0.101 \\
0.449 \\
0.9541 \\
10.91 \\
0.21\end{array}$ & $\begin{array}{c}0.174 \\
0.496 \\
0.9776 \\
15.55 \\
0.27\end{array}$ & $\begin{array}{c}0.196 \\
0.452 \\
0.9561 \\
10.90 \\
0.30\end{array}$ & $\begin{array}{c}0.185 \\
0.453 \\
0.9561 \\
10.55 \\
0.29\end{array}$ & $\begin{array}{c}0.381 \\
0.452 \\
0.9561 \\
10.73 \\
0.42\end{array}$ & $\begin{array}{c}0.146 \\
0.450 \\
0.9552 \\
10.56 \\
0.26\end{array}$ \\
\hline
\end{tabular}




\section{Cost modelling for flotation machines}

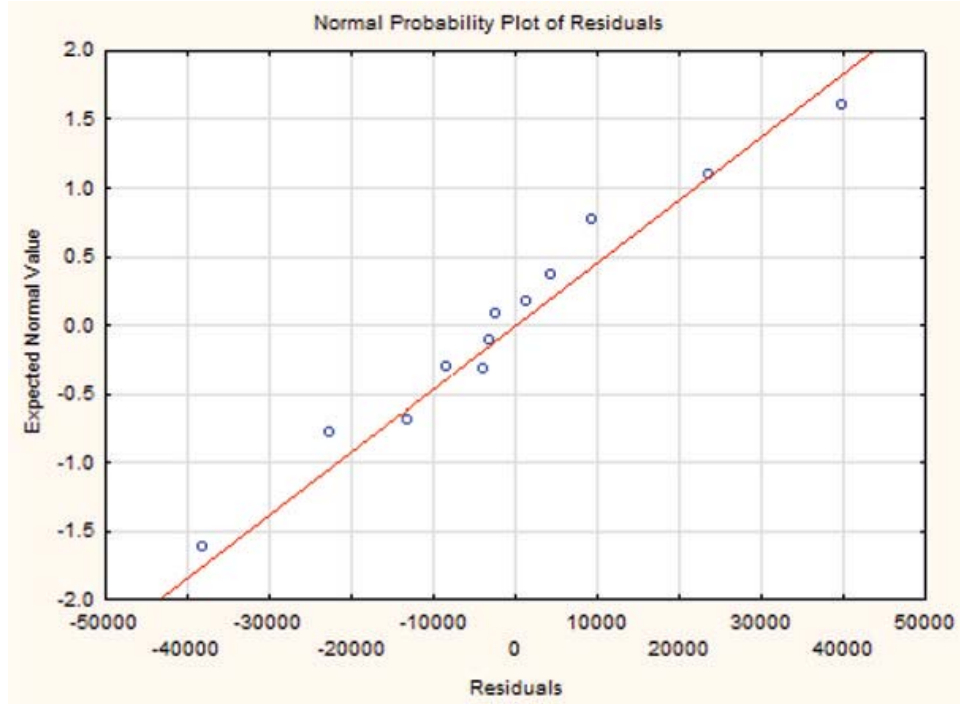

Figure 4-Residual analysis for MVR capital cost of the CSFM

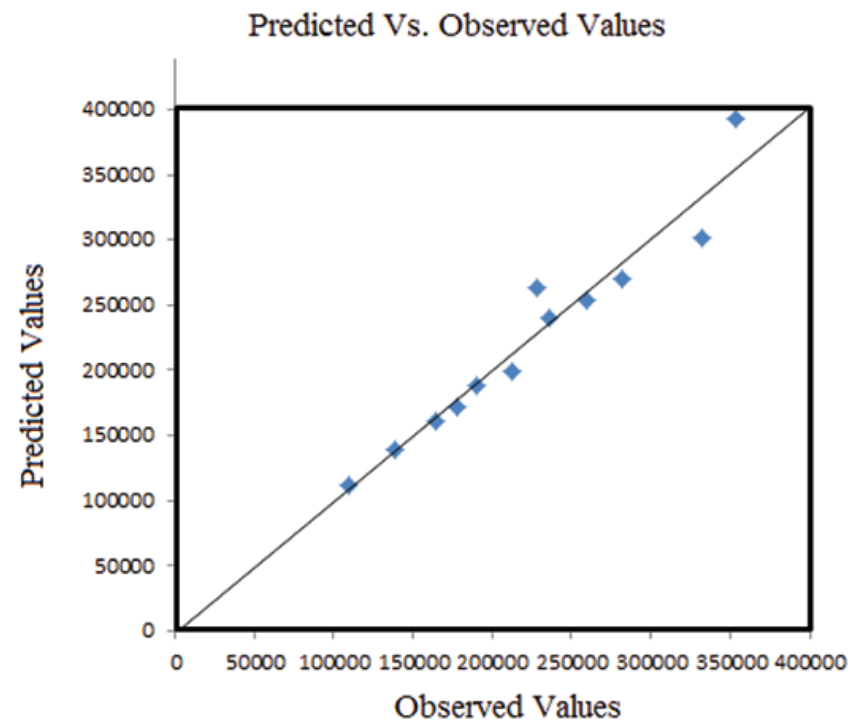

Figure 5-Observed vs. predicted values of MVR capital cost for the CSFM

with the MAER. As an example, the validity of the developed model in reproducing the measured data of capital costs for the CSFM machine is demonstrated in Figure 5.

\section{Cost model for variable-speed DC motors}

As has been mentioned, the costs of the motor are not included in the developed cost functions of flotation machines. Therefore, when a flotation cell is chosen and its costs are estimated, the capital and operating costs of the relevant motor (based on the required power $(P)$ in $\mathrm{kW}$ ) can be estimated by Equations [12] and [13]. Motors are assumed to be variable speed with $1150 \mathrm{r} / \mathrm{min}$ drive rating. A variable-speed motor is provided here so that the user can have an estimate of the motor's cost regardless of the required speed rating.

$$
C C=863.6 \times P^{0.7186} \quad \mathrm{R}^{2}=0.9952, \text { MAER }=3 \%
$$

$$
O C=0.1114 \times P^{0.9344} \quad \mathrm{R}^{2}=0.9998, \text { MAER }=1 \%
$$

\section{Discussion}

Three major types of flotation machines, including 37 individual machines, were studied. The explanatory variable in SRA was either diameter or cell volume; whereas in MRA (depending on the machine type), different technical variables such as diameter, required air flow rate, required floor space, cell volume, required air pressure, and power were considered as predictor variables simultaneously.

The models were classified into capital and operating costs. Moreover, the operating cost was detailed in different cost items. The cost models are valid within a certain range, indicated in Table II, and major extrapolation should be avoided. 


\section{Cost modelling for flotation machines}

\begin{tabular}{|c|c|c|c|c|c|c|c|c|c|c|c|}
\hline \multirow{3}{*}{$\begin{array}{l}\text { Machine } \\
\text { type }\end{array}$} & \multirow{3}{*}{$\begin{array}{l}\text { Explanatory } \\
\text { variables }\end{array}$} & \multirow[t]{3}{*}{ Coefficients } & \multirow[t]{3}{*}{ Capital cost } & \multicolumn{7}{|c|}{ Operating costs } & \multirow{3}{*}{$\begin{array}{l}\text { Lubrication } \\
\text { cost }\end{array}$} \\
\hline & & & & \multirow{2}{*}{$\begin{array}{c}\text { Total operating } \\
\text { costs }\end{array}$} & \multicolumn{3}{|c|}{ Overhaul } & \multicolumn{3}{|c|}{ Maintenance } & \\
\hline & & & & & Parts & Labour & Total & Parts & Labour & Total & \\
\hline \multirow{5}{*}{$\begin{array}{l}\text { Column, } \\
\text { sulphide }\end{array}$} & Intercept & $\mathrm{a}_{0}$ & 55057.22 & 1.5927 & 0.2284 & 0.2129 & 0.4272 & 0.4272 & 0.3947 & 0.8219 & 0.3112 \\
\hline & $\mathrm{D}$ & $a_{1}$ & 70938.63 & 2.0429 & 0.2974 & 0.2801 & 0.5478 & 0.5478 & 0.5219 & 1.0697 & 0.4070 \\
\hline & $\mathrm{AF}$ & $\mathrm{a}_{2}$ & 36.7212 & 0.0011 & 0.0001 & 0.0001 & 0.0003 & 0.0003 & 0.0003 & 0.0005 & 0.0002 \\
\hline & MAER & & 4.98 & 4.98 & 4.94 & 5.07 & 5.04 & 5.04 & 4.93 & 4.98 & 5.08 \\
\hline & $\mathrm{R}^{2}$ & & 0.9417 & 0.9416 & 0.9427 & 0.9409 & 0.9408 & 0.9408 & 0.9420 & 0.9414 & 0.9417 \\
\hline \multirow{5}{*}{$\begin{array}{l}\text { Column, } \\
\text { Coal }\end{array}$} & Intercept & $a_{0}$ & -7769.630 & -0.19900 & -0.0088 & -0.0359 & -0.0448 & -0.0235 & -0.0431 & -0.0667 & -0.06008 \\
\hline & D & $a_{1}$ & 88745.590 & 2.54599 & 0.35875 & 0.34856 & 0.70731 & 0.66826 & 0.64232 & 1.31059 & 0.51409 \\
\hline & $\mathrm{AF}$ & $\mathrm{a}_{2}$ & -26.29080 & -0.00075 & -0.0001 & -0.0001 & -0.0002 & -0.0002 & -0.0002 & -0.0003 & -0.00016 \\
\hline & MAER & & 3.3 & 3.3 & 3.42 & 3.4 & 3.41 & 3.28 & 3.33 & 3.31 & 3.37 \\
\hline & $\mathrm{R}^{2}$ & & 0.9509 & 0.9509 & 0.9471 & 0.9495 & 0.9483 & 0.9511 & 0.9493 & 0.9502 & 0.9490 \\
\hline \multirow{6}{*}{$\begin{array}{l}\text { Self- } \\
\text { aerating }\end{array}$} & Intercept & $a_{0}$ & 24976.6 & 0.7206 & 0.1021 & 0.0951 & 0.1971 & 0.1951 & 0.1840 & 0.3791 & 0.1425 \\
\hline & $\mathrm{CV}$ & $a_{1}$ & 4130.6 & 0.1190 & 0.0172 & 0.0160 & 0.0331 & 0.0327 & 0.0304 & 0.0632 & 0.0236 \\
\hline & FS & $\mathrm{a}_{2}$ & 1114.9 & 0.0319 & 0.0045 & 0.0050 & 0.0094 & 0.0086 & 0.0078 & 0.0164 & 0.0068 \\
\hline & $\mathrm{P}$ & a3 & -624.4 & -0.0179 & -0.0025 & -0.0024 & -0.0049 & -0.0051 & -0.0047 & -0.0098 & -0.0036 \\
\hline & MAER & & 13.48 & 13.55 & 13.09 & 13.88 & 13.45 & 13.19 & 13.56 & 13.37 & 13.43 \\
\hline & $\mathrm{R}^{2}$ & & 0.9940 & 0.9939 & 0.9943 & 0.9939 & 0.9941 & 0.9941 & 0.9940 & 0.9940 & 0.9937 \\
\hline \multirow[t]{7}{*}{ Standard } & Intercept & $a_{0}$ & 30240.78 & 0.8330 & 0.1216 & 0.1146 & 0.2241 & 0.2307 & 0.2162 & 0.4469 & 0.1728 \\
\hline & CV & $a_{1}$ & -5415.50 & -0.1552 & -0.0241 & -0.0206 & -0.0527 & -0.0419 & -0.0396 & -0.0814 & -0.0306 \\
\hline & $\mathrm{AF}$ & $a_{2}$ & 10220.11 & 0.2944 & 0.0422 & 0.0392 & 0.0871 & 0.0795 & 0.0739 & 0.1534 & 0.0573 \\
\hline & AP & $a_{3}$ & -13354.40 & -0.3664 & -0.0568 & -0.0472 & -0.1242 & -0.1011 & -0.0944 & -0.1955 & -0.0746 \\
\hline & $\mathrm{P}$ & $a_{4}$ & 2312.0450 & 0.0649 & 0.0111 & 0.0085 & 0.0252 & 0.0175 & 0.0170 & 0.0345 & 0.0133 \\
\hline & MAER & & 3.05 & 5.05 & 3.56 & 2.56 & 11.78 & 3.4 & 3.06 & 3.12 & 2.81 \\
\hline & $\mathrm{R}^{2}$ & & 0.9997 & 0.9993 & 0.9996 & 0.9997 & 0.9988 & 0.9996 & 0.9997 & 0.9996 & 0.9997 \\
\hline
\end{tabular}

The most expensive machine is a type of flotation column that has capital and operating costs of about $\$ 394000$ and $\$ 11$ per hour, respectively. The capital cost of a CSFM and CCFM is proportional to the 0.79 and 0.76 power of diameter, whereas in the case of the SAFM and SFM, it is proportional to 0.47 and 0.45 of the cell volume, respectively. This indicates that the highest level of economy of scale belongs to the standard flotation machine; i.e. the SFM cost advantage increases with increasing size of the machine. The $\mathrm{R}^{2}$ values between $0.87 \%$ and $0.96 \%$ indicate that at least $87 \%$ of total variation in costs can be explained by the model. The lowest MAER of SRA belongs to the CSFM (4.86\%) that designates the cost model with the maximum accuracy. In the MRA cases, this property is owed to the SFM (3.05\%).

\section{Conclusion}

Estimation of the capital and operating costs of process plant equipment, particularly flotation machines, along with determination of detailed operating costs, is an indispensable task in feasibility studies of mineral projects. Almost all of the current models are obsolete and need to be updated. Moreover, the majority of the available models have a univariate structure, and the role of other operative variables has simply been disregarded. A new up-to-date statistical cost model for flotation machines (column as well as coal and sulphide, self-aerating, and standard) has been developed.

Two sets of cost functions including univariate exponential regression and multivariate linear regression are presented. Individual cost functions are presented for each operational cost item category such as overhaul (parts and labour), maintenance (parts and labour), power and lubrication items. However, costs can vary from mine to mine and from time to time, and should be adjusted for conditions specific to the operation based on local unit costs (such as electrical power, lubricants, and repair labour), and annual cost index of mineral processing equipment. The proposed cost models are reliable in device specifications ranged as noted in Table II, and over- extrapolation could result in misguiding estimates.

The MAER, RMSE, $\mathrm{R}^{2}$, and residual analysis methods were applied for the evaluation of the models. Maximum MAER of $13.5 \%$ and minimum $\mathrm{R}^{2}$ of 0.86 indicate that these models can be used as a reliable tool in cost estimation of flotation machines at the pre-feasibility and even feasibility study level of projects. 


\section{Cost modelling for flotation machines}

\section{References}

CAMm, T.W. 1994. Simplified cost models for prefeasibility mineral evaluations. Mining Engineering, vol. 46, no.6. pp. 559-562.

HuAng, X. X., Newnes, L. B., and PARRY, G.C. 2012. The adaptation of product cost estimation techniques to estimate the cost of service. International Journal of Computer Integrated Manufacturing, vol. 25, no. 4-5. pp. $417-431$.

INFOMINE. 2013. Mine and mill equipment costs. InfoMine USA, Inc. CostMine Division and Aventurine Engineering, Inc.

KAISER, H.F. 1960. The application of electronic computers to factor analysis. Educational and Psychological Measurement, vol. 20. pp. 141-151.

Khalesi, M. R., Zarei, M. J., Sayadi, A. R., Khoshnam, F., and Chegeni, M. H. 2015. Development of a techno-economic simulation tool for an improved mineral processing plant design. Minerals Engineering, vol. 81 . pp. 103-108.

KIM, G.H., AN, S.H., and KANG, K.I. 2004. Comparison of construction cost estimating models based on regression analysis, neural networks, and case-based reasoning. Building and Environment, vol. 39, no. 10. pp. 1235-1242.

LASHGARI, A. and SAYADI, A.R. 2013. Statistical approach to determination of overhaul and maintenance cost of loading equipment in surface mining, International Journal of Mining Science and Technology, vol. 23. pp. 441-446.

LoH, H.P., Lyons, J., and White, C.W. 2002. Process equipment cost estimation, final report. National Energy Technoloy Center, DOE/NETL-2002/1169.

Mcnab, B., Jancovic, A., David, D., and Payne, P. 2009. Processing of magnetite iron ores-comparing grinding options. Proceedings of the AusIMM Iron Ore Conference, Perth, WA, 27-29 July 2009.

Mohutsiwa, M. and Musingwini, C. 2015. Parametric estimation of capital costs for establishing a coal mine: South Africa case study. Journal of the Southern African Institute of Mining and Metallurgy, vol. 115. pp. 789-797.

Montgomery, D.C. and Runger, G.C. 2003. Applied Statistics and Probability for Engineers. 3rd edn. Arizona State University.

Mular, A.L. 1978. Mineral Processing Equipment Costs and Preliminary Capital Cost Estimations. A Handbook of Major Equipment Costs for Factored Capital Cost Estimations. Canadian Institute of Mining and Metallurgy, Montreal. vol.13. 166 pp.

Mular, A.L. 1982. Mining and Mineral Processing Equipment Costs and Preliminary Capital Cost Estimations. Special Volume 25. Canadian Institute of Mining and Metallurgy, Montreal. $265 \mathrm{pp}$.

Mular, A.L. and Poulin, R. 1998. Capcosts 1998. A Handbook for Estimating Mining and Mineral Processing Equipment Costs and Capital Expenditures and Aiding Mineral Project Evaluations. Special Volume 47. Canadian Institute of Mining and Metallurgy, Montréal. 319 pp.

Niazi, A., Dai, J.S., Balabani, S., and Seneviratne, L. 2006. Product cost estimation technique classification and methodology review. Journal of Manufacturing Science and Engineering, vol. 128. pp. 563-575.

NoAKES, M. and LANZ, T. 1993. Cost estimation handbook for the Australian mining industry. Australasian Instiute of Mining and Metallurgy, Carlton, Victoria. $412 \mathrm{pp}$.

O'HARA, T.A. 1980. Quick guide to the evaluation of ore bodies, CIM Bulletin, February. pp. 87-89.

O'HARA T. A. and SubolesK, I C.S. 1992. Costs and cost estimation. SME Mining Engineering Handbook. Vol. 1. Society for Mining, Metallurgy and Exploration, Littleton, CO. Chapter 6.3, pp. 405-424.

PASCOE, R.D. 1992. Capital and operating costs of minerals engineering plants: a review of simple estimation techniques. Minerals Engineering, vol. 5, no. 8. pp. 883-893.

PRASAD, L. 1969. Mineral processing plant design and cost estimation. Processors Division of the Canadian Institute of Mining, Metallurgy and Petroleum, Montreal. pp. 3-15.

SAyadi, A.R., LASHgari, A., and PARAsZczaK, J.J. 2011. Hard-rock LHD cost estimation using single and multiple regressions based on principal component analysis. Tunnelling and Underground Space Technology, vol. 27. pp.133-141

SAyadi, AR., Lashgari, A., Fouladgar, M.M., and Skibniewski, M.J. 2012. Estimating capital and operational costs of backhoe shovels. Journal of Civil Engineering and Management, vol. 18, no. 3. pp 378-385.

Sayadi, A.R., Khalesi, M.R., and Khosfarman, M. 2014. A parametric cost model for mineral grinding mills. Minerals Engineering, vol. 55. pp. 96-102.

SMith, A.E. and MASON, A.K. 1997. Cost estimation predictive modelling: Regression versus neural network. The Engineering Economist, vol. 42 no. 2. pp. 137-161.

STEBBins, S.A. 1987. Cost estimation handbook for small placer mines. Information Circular 9170, 94. US Bureau of Mines.

Tımm, N.H. 2002. Applied Multivariate Analysis. Springer-Verlag, New York.

USBM. 1987. US Bureau of Mines cost estimating system handbook, Mining and beneficiation of metallic and non-metallic minerals expected fossil fuels in the United States and Canada. Open file report 10-87. US Bureau of Mines, Denver, CO. 134 pp.

Wills, B.A. and NAPIER-MunN, T. 2011. Wills' Mineral Processing Technology: An Introduction to the Practical Aspects of Ore Treatment and Mineral Recovery. 7th edn. Elsevier/Butterworth Heinemann, Amsterdam. 